\title{
Research on the Impact of Performance Compensation Commitment on Backdoor Listing Companies Earnings Management
}

\author{
Zhang Menghan ${ }^{1}$ \\ ${ }^{1}$ School of Economics and Management Beijing Jiaotong University Beijing, China
}

\begin{abstract}
Based on the data of Chinese A-share listed companies during the period from 2007 to 2016, this paper examined the impact of the performance compensation commitments in backdoor listing on corporate earnings management. The empirical results show that performance commitments have increased backdoor listed companies' earnings management level; the promised performance growth rate is positively correlated with earnings management level; share compensation has a stronger impact on earnings management than cash compensation. In addition, compared with state-owned enterprises, the association between performance compensation commitments and earnings management is more pronounced in non-state-owned firms.
\end{abstract}

\section{INTRODUCTION}

Asset restructuring is one of the essential ways for companies to adjust resource allocation. Compared with general asset restructuring, the backdoor listing is a unique and complex transaction involving multiple stakeholders. Backdoor listing not only makes a company grow more energetic, but also brings risks to enterprises. The most critical issue in this transaction is how to value the profitability of the target in the future. This uncertainty will bring risks to the companies, so parties to the transaction often have differences in how to price. Since the two parties in the transaction have a different understanding of the underlying asset, the information transmitted will be changed at this time, which is not fair to the transaction parties. Thus how to maintain the fairness of the asset transaction has become the focus of attention.

However, performance compensation commitments in acquisition can solve this problem to a certain extent, and it also brings a crisis that the target company cannot fulfil the promise. China's performance commitment system is not yet perfect, which leads to many speculative behaviours of the target company. In order to achieve the promised profits and avoid high compensation, the target company tends to adopt earnings management to optimize performance, which misleads the outside public and finally harms the interests of investors. Therefore, it is of profound significance to study the performance commitment and earnings management in backdoor listings.

The remainder of the paper is organized into five sections. Section 2 provides a review of the relevant literature. In section 3, we develop our hypotheses. In section 4, we discuss the sample, variables and models used

mhzhang1012@163.com in the analyses. Section 5 presents the empirical results and the final section concludes.

\section{LITERATURE REVIEW}

\subsection{Performance compensation commitments}

Based on our research content, this paper mainly analyzes the literature about the application consequences of performance compensation commitments. The effect of performance commitments on transaction entities of M\&A has two sides, both positive and negative.

First of all, performance compensation promises have a positive impact on improving corporate performance. Lu Changjiang et al. found that the target company will convey to the acquirer confidence in future performance when they make commitments. And for the acquirer, it can increase their risk judgment ability and improve the company's synergy of M\&A [1]. Pan Ailing et al. believe that performance commitment has a significant incentive effect on the performance of the target company after M\&A [2]. Secondly, performance compensation promises also play a role in protecting the interests of small shareholders [3]. Besides, there are some research results on the specific provisions of commitments and company performance [4]. For example, equity compensation improve company performance better than cash compensation, two-way performance commitments have better incentive effects than one-way.

However, performance compensation commitments in practice will harm minority shareholders' interests due to substandard performance. In order to obtain the "high premium" given by the acquirer, the acquired company has a "high commitment", which is always "low fulfilment". Once the high commitment cannot be realized, it may cause 
the stock price to fluctuate significantly [5]. What's more, mandatory unilateral performance commitments will hinder integration activities after M\&A and affect the longterm development of the company [6]. And promised performance growth rate will have an inverted U-shaped impact on the integration effect, that is, excessive-high promised rate will reduce the integration effect [7].

\subsection{Performance commitment and earnings management}

Due to the insufficient performance commitment system, the target company has speculative behavior in the process of implementing performance commitments. When the promised performance cannot be achieved, the acquired company is most likely to adopt earnings management to whitewash its performance and reduce the amount of compensation.

In terms of specific provisions of commitments and earnings management, Hou finds that the higher the promised profitability, the higher the earnings management level [8]. Cadman finds that when the commitment is difficult to complete, companies that sign two-way performance compensation commitments are more inclined to carry out earnings management than one-way [9]. In terms of the selection of earnings management methods, because most performance commitment periods are three years, companies that carry out accrual earnings management cannot avoid the negative impact of accrual reversals in the remaining commitment years. However, real earnings management only affects the current period and can be carried out at any time within a fiscal year, without accounting treatment and reversal issues. Therefore, companies with performance compensation commitments are more inclined to adopt real earnings management (Liu Hao et al.; Wang Ping). Based on this, this paper adopts real earnings management variables to measure the company's earnings management level.

\section{HYPOTHESES DEVELOPMENT}

\subsection{Performance compensation commitment in backdoor listing and earnings management}

First of all, during the performance commitment period, backdoor company's controlling shareholders bear greater compensation pressure. If the promised profit cannot be fulfiled, the amount of compensation must be calculated based on the purchase price of the asset. Compared with other reorganizations' compensation amount that is calculated by the difference between actual profit and promised profit, backdoor listing company' amount is often higher. And shell company has the right to repurchase the compensated shares at a lower price, which may cause backdoor listed company's controlling shareholders to lose their shareholding advantage. In addition, the excessive gap between the promised profit and the actual profit may attract the attention of the regulatory authorities. In serious cases, the controlling shareholder may also be subject to corresponding administrative penalties or even legal sanctions. Therefore, performance commitments have brought heavy pressure to listed companies and strengthened the controlling shareholders' motivation to avoid falling profits. The above discussion leads to our first hypothesis:

H1: Backdoor listed companies with signed performance commitment contracts, have higher earnings management level, than those without.

\subsection{Characteristics of specific performance commitment provisions and earnings management}

\subsubsection{Promised performance growth rate and earnings management}

According to the signal transmission theory, in order to achieve listing as soon as possible, a backdoor company will send a good signal to the market by signing a performance commitment with a high performance growth rate. However, the higher the promised rate, the greater the risk that cannot be realized before the agreements expire. If the backdoor listed company cannot fulfill its performance commitment before the commitment expires, it needs to make stock or cash compensation to the shell company. The method of equity compensation will weaken the control of major shareholders; the method of cash compensation reduces the current assets, which is not conducive to the company's operating turnover. At this time, in order to avoid compensation, the managers of backdoor listed company will ignore the company's longterm development and manipulate profits. The larger the scale of promised profit by the backdoor company, the more likely they are to take earnings management. This leads to following hypothesis:

H2a: The performance growth rate promised by backdoor listed companies is positively correlated with the earnings management level.

\subsubsection{Promised performance compensation method and earnings management}

If the performance compensation method is share compensation, the shareholders will compensate the shares when the actual performance does not meet the agreement, which will threaten the shareholders' equity of the backdoor listed company. If too many shares are compensated, it will even lead to a change of control. However, if listed companies choose cash compensation, they only need to make up the amount of unrealized performance, which poses less threat to the shareholders of the backdoor company. The share compensation method has a more serious impact than the cash compensation method. Therefore, if the compensation method in the performance commitment agreement is share compensation, the management of the backdoor company has greater incentives to carry out earnings management to avoid losing their interests when the performance promise is not fulfiled. Based on above discussion, we posit the following hypothesis: 
$\mathrm{H} 2 \mathrm{~b}$ : Share compensation has a stronger impact on earnings management of backdoor listed company than cash compensation.

\subsection{Moderating effect of property right nature}

On the one hand, the difference in property rights nature leads to different business objectives between state-owned enterprises and non-state-owned enterprises. Chen Binkai and Lin Yifu believe that the main goal of state-owned enterprises is to actively respond to the policies issued by the government and fulfill their responsibilities to the public [10]. However, the non-state-owned enterprises' main goal is to maximize their interests. Therefore, nonstate-owned enterprises are more likely to use performance promises to increase the transaction price of the underlying assets, and use earnings management during the performance promise period to realize the promised performance.

On the other hand, the fulfilment of performance promises has different effects on state-owned enterprises and non-state-owned enterprises. If the backdoor listed company fulfills its performance commitments, it' $\mathrm{s}$ operations will be more favored by investors, so the company's equity has a higher transfer value, which further increases the motivation of non-state-owned enterprise's shareholders to obtain benefits through earnings management. On the contrary, state-owned enterprises will also receive more policy support when their promised performance cannot be achieved, but non-state-owned enterprises must make compensation through their own shares or cash when the target performance is not achieved, that is, the relationship between earnings management and performance failure is more direct in non-state-owned companies. This leads to our third hypothesis:

H3: Compared with state-owned enterprises, the association between performance compensation commitments and earnings management is more pronounced in non-state-owned firms

\section{RESEARCH DESIGN}

\subsection{Sample and data}

To form our samples, we begin with all announced and completed Chinese backdoor listing with announcement dates between January 1, 2007 and December 31, 2016 from Chinese Acquisition Database of Wind Info and CSMAR. We require that: (a) eliminate the sample in which one of the counterparty belongs to financial industry; (b) eliminate the data-missing samples. After the above screening, we obtain 192 backdoor listing samples.

\subsection{Measurement of key variables}

\subsubsection{Dependent variable}

According to previous literature, we find that companies are more inclined to choose real earnings management. Therefore, this paper uses real earnings management as the explained variable, denoted by REM. We select production manipulation, expense manipulation, and sales manipulation indicators to measure real earnings management variable and use abnormal production costs, abnormal discretionary expenses and abnormal operating cash flow to measure the above three real earnings management methods.

\subsubsection{Independent variables}

Firstly, we use PRO to represent whether the performance compensation commitment agreements are signed. This variable is a dummy variable. If shell company and backdoor company signed a performance commitment contract, PRO takes 1 , otherwise, takes 0 . Then we use RPRO to represent promised performance growth rate. Finally, we use CPRO to represent promised performance compensation method, which is a dummy variable. If it's share compensation, PRO takes 1 , otherwise, takes 0 .

\subsubsection{Moderator variable}

We use SOE to represent the property right nature of backdoor listed company. This variable is a dummy variable. If the backdoor listed company is state-owned one, SOE takes 1 , otherwise, takes 0 .

\subsubsection{Control variables}

We select firm's size(Size), total long-term debts (Lev), return on total equity (ROE), the ratio of inventory to total asset(INV), CEO/ Chairman separation (CEO), the shareholding ratio of institutional investor (IDP), the shareholding ratio of the largest shareholder (Top1), firm's growth (Growth), firm's industry (INDUSTRY) and firm's year (YEAR) as control variables.

\subsection{Model}

This article refers to the model establishment methods of Pan Ailing and Qiu Jinlong (2017), Rao Qian (2017) and Zhang Haiqing (2020), selects the corresponding control variables, and uses multiple linear regression models and nonlinear regression models to verify the relationship between explanatory variables and explained variables. In order to test hypothesis 1 , this paper establishes model (1):

$$
\begin{aligned}
\mathrm{REM}= & \beta_{0}+\beta_{1} \mathrm{PRO}+\beta_{2} \mathrm{SIZE}+\beta_{3} \mathrm{LEV}+ \\
& \beta_{4} \mathrm{ROE}+\beta_{5} \mathrm{INV}+\beta_{6} \mathrm{CEO}+\beta_{7} \mathrm{IDP}+ \\
& \beta_{8} \mathrm{GROWTH}+\beta_{9} \text { YEAR }+\varepsilon
\end{aligned}
$$

In order to test hypothesis $2 \mathrm{a}$ and $2 \mathrm{~b}$, this paper establishes model (2) and (3):

$$
\begin{aligned}
\text { REM }= & \beta_{0}+\beta_{1} \text { CPRO }+\beta_{2} \text { SIZE }+\beta_{3} \mathrm{LEV}+ \\
& \beta_{4} \text { ROE }+\beta_{5} \text { INV }+\beta_{6} \text { CEO }+\beta_{7} \text { IDP }+ \\
& \beta_{8} \text { GROWTH }+\beta_{9} \text { YEAR }+ \\
& \beta_{10} \text { INDUSTRY }+\varepsilon \\
\text { REM }= & \beta_{0}+\beta_{1} \text { RPRO }+\beta_{2} R P R O^{2}+\beta_{3} \text { SIZE }+ \\
& \beta_{4} \text { LEV }+\beta_{5} \text { ROE }+\beta_{6} \text { INV }+\beta_{7} \text { CEO }+ \\
& \beta_{8} \text { IDP }+\beta_{9} \text { GROWTH }+\beta_{10} \text { YEAR }+ \\
& \beta_{11} \text { INDUSTRY }+\varepsilon
\end{aligned}
$$

In order to test hypothesis 3 , this paper establishes model (4):

$$
\mathrm{REM}=\beta_{0}+\beta_{1} \mathrm{PRO}+\beta_{2} \mathrm{SOE}+\beta_{3} \mathrm{PRO} \times \mathrm{SOE}+
$$


$\beta_{8} \mathrm{CEO}+\beta_{9} \mathrm{IDP}+\beta_{10} \mathrm{GROWTH}+$ $\beta_{11}$ YEAR $+\beta_{12}$ INDUSTRY $+\varepsilon$

\section{EMPIRICAL ANALYSES}

\subsection{Descriptive statistics}

Table I presents descriptive statistics for our variables. The maximum of REM is 0.6988 , the median is 0.1381 , and the minimum is -0.2384 , indicating that in the sample of this article, the company's degree of positive earnings management is 0.6988 , and the negative is 0.2384 , that is, most sample companies have positive earnings management.

The average of PRO is 0.7860 , indicating that $78.60 \%$ of the sample companies choose to sign performance commitments in backdoor listing; The average of CPRO is 0.7654, indicating that more backdoor companies choose share compensation; The maximum RPRO is $92.98 \%$, the minimum value is 0 , indicating that there is a big difference between the net profit growth rates agreed by different sample companies.

The average of SOE is 0.4654 , indicating that nearly half of the sample companies are state-owned enterprises.

Table I Descriptive statistics

\begin{tabular}{|c|c|c|c|c|c|c|}
\hline VarName & Obs & Mean & Std. dev. & Minimum & Median & Maximum \\
\hline REM & 192 & 0.0907 & 0.1395 & -0.2384 & 0.1381 & 0.6988 \\
\hline PRO & 192 & 0.7860 & 0.2820 & 0.0000 & 0.7020 & 1.0000 \\
\hline CPRO & 192 & 0.7654 & 0.5430 & 0.0000 & 0.7140 & 1.0000 \\
\hline RPRO & 192 & 0.3625 & 0.2654 & 0.0000 & 0.1831 & 0.9298 \\
\hline SOE & 192 & 0.4654 & 0.4839 & 0.0000 & 0.5420 & 1.0000 \\
\hline SIZE & 192 & 20.7264 & 0.9668 & 13.2659 & 20.7028 & 25.8202 \\
\hline LEV & 192 & 0.4615 & 0.2207 & 0.0424 & 0.4453 & 0.9369 \\
\hline ROE & 192 & 0.2084 & 0.2266 & -0.2346 & 0.0308 & 0.8487 \\
\hline INV & 192 & 0.1332 & 0.1231 & 0.0000 & 0.1204 & 0.8606 \\
\hline CEO & 192 & 0.2596 & 0.4405 & 0.0000 & 0.2090 & 1.0000 \\
\hline IDP & 192 & 0.3497 & 0.0460 & 0.2333 & 0.3333 & 0.5556 \\
\hline TOP1 & 192 & 0.2877 & 0.1257 & 0.0750 & 0.2703 & 0.7193 \\
\hline GROWTH & 192 & 2.6283 & 0.8508 & -0.7040 & 0.3088 & 9.5401 \\
\hline
\end{tabular}

\subsection{Correlation matrix}

Table II presents pooled Spearman correlations between the variables. In the backdoor listing, PRO and REM have a strong positive correlation $(\mathrm{r}=0.180, \mathrm{p}=0.01)$, which is consistent with the expected result of hypothesis 1 . CPRO, RPRO and REM have a strong positive correlation at the $1 \%$ confidence level, which meets the expected results of hypothesis $2 \mathrm{a}$ and $2 \mathrm{~b}$. SOE and REM have a strong negative correlation $(\mathrm{r}=-0.149, \mathrm{p}=0.01)$, which is in line with the expected results of hypothesis 3 .

Table II Spearman correlation matrix

\begin{tabular}{|c|c|c|c|c|c|}
\hline & REM & PRO & $\mathrm{CPRO}$ & RPRO & SOE \\
\hline REM & 1 & & & & \\
\hline PRO & $0.180 * * *$ & 1 & & & \\
\hline CPRO & $0.168 * * *$ & - & 1 & & \\
\hline RPRO & $0.201 * * *$ & - & 0.117 & 1 & \\
\hline SOE & $\frac{-}{-}$ & $\begin{array}{c}- \\
0.172^{* * *}\end{array}$ & -0.056 & 0.178 & 1 \\
\hline SIZE & $0.021 * *$ & $0.001 * *$ & -0.031 & $0.023 * *$ & $0.185 * * *$ \\
\hline LEV & $0.152 * *$ & $\begin{array}{c}- \\
0.125^{* * *}\end{array}$ & $\begin{array}{c}- \\
0.062^{* * *}\end{array}$ & 0.059 & $0.098 * * *$ \\
\hline ROE & $0.126 * * *$ & $0.148 * * *$ & $-0.028 *$ & -0.112 & -0.105 \\
\hline INV & $0.086^{*}$ & $\overline{-}^{-}$ & -0.102 & 0.065 & -0.156 \\
\hline CEO & $0.078 * * *$ & $-0.073 *$ & -0.061 & -0.003 & -0.021 \\
\hline IDP & ${ }^{-}-124^{* * *}$ & $0.210 * * *$ & $-0.098 * *$ & 0.049 & -0.086 \\
\hline GROWTH & $0.089 * *$ & $0.18 * * * 2$ & 0.084 & -0.031 & 0.097 \\
\hline
\end{tabular}

Note: *, **, and *** denote significance at levels of $0.1,0.05$, and 0.01 using two-tailed tests, respectively.

\subsection{Empirical results}

Table III reports the test results of the model (1) (2) (3). According to Table 3 (2), after adding the control variables, the coefficient of PRO is $-0.126(p=0.01)$, which supports $\mathrm{H} 1$, indicating that performance compensation commitments has increased backdoor listed companies' earnings management level. Next, the results verify Hypothesis $2 a$ and $2 b$. Columns (3) report that the coefficient of CPRO is $0.282(\mathrm{p}=0.01)$, indicating that share compensation has a stronger impact on earnings management of backdoor listed company than cash 
compensation. Columns (4) report that the coefficient of RPRO is $0.162(\mathrm{p}=0.01)$, indicating that the promised

performance growth rate is positively correlated with earnings management level.

Table III Empirical results of H1,H2a and H2b

\begin{tabular}{|c|c|c|c|c|}
\hline & $\begin{array}{c}(1) \\
\text { REM }\end{array}$ & $\begin{array}{c}(2) \\
\text { REM }\end{array}$ & $\begin{array}{c}(3) \\
\text { REM }\end{array}$ & $\begin{array}{c}(4) \\
\text { REM }\end{array}$ \\
\hline PRO & & $\begin{array}{c}-0.126 * * * \\
(-4.621)\end{array}$ & & \\
\hline CPRO & & & $\begin{array}{c}0.282 * * * \\
(-8.634)\end{array}$ & \\
\hline RPRO & & & & $\begin{array}{c}0.162 * * * \\
(6.515)\end{array}$ \\
\hline RPRO2 & & & & $\begin{array}{c}0.054 * * * \\
(-5.681)\end{array}$ \\
\hline SIZE & $\begin{array}{c}0.014 * * * \\
(4.871)\end{array}$ & $\begin{array}{c}0.015^{* * *} \\
(4.892)\end{array}$ & $\begin{array}{c}0.013 * * * \\
(6.575)\end{array}$ & $\begin{array}{c}0.013 * * * \\
(6.542)\end{array}$ \\
\hline LEV & $\begin{array}{c}0.139 * * * \\
(8.907)\end{array}$ & $\begin{array}{c}0.132 * * * \\
(8.845)\end{array}$ & $\begin{array}{c}0.130 * * * \\
(5.443)\end{array}$ & $\begin{array}{c}-0.132 * * * \\
(7.395)\end{array}$ \\
\hline ROE & $\begin{array}{c}0.654 * * * \\
(5.917)\end{array}$ & $\begin{array}{c}0.652 * * * \\
(-3.919)\end{array}$ & $\begin{array}{c}0.629 * * * \\
(4.259)\end{array}$ & $\begin{array}{c}0.628^{* * * *} \\
(4.268)\end{array}$ \\
\hline INV & $\begin{array}{l}0.069^{*} \\
(1.601)\end{array}$ & $\begin{array}{l}0.065^{*} \\
(1.862)\end{array}$ & $\begin{array}{c}0.060^{*} \\
(1.7674)\end{array}$ & $\begin{array}{c}0.062^{*} \\
(1.7727)\end{array}$ \\
\hline CEO & $\begin{array}{c}0.016 \\
(-1.233)\end{array}$ & $\begin{array}{c}-0.015 \\
(-1.144)\end{array}$ & $\begin{array}{c}0.020 \\
(1.040)\end{array}$ & $\begin{array}{c}0.020 \\
(1.016)\end{array}$ \\
\hline IDP & $\begin{array}{c}-0.176^{* * *} \\
(-3.450)\end{array}$ & $\begin{array}{c}-0.177 * * * \\
(-3.516)\end{array}$ & $\begin{array}{c}-0.180 * * * \\
(-4.231)\end{array}$ & $\begin{array}{c}0.180 * * * \\
(-4.569)\end{array}$ \\
\hline GROWTH & $\begin{array}{c}0.003 * * \\
(2.236)\end{array}$ & $\begin{array}{c}0.003 * * \\
(2.319)\end{array}$ & $\begin{array}{c}0.004 * * \\
(2.562)\end{array}$ & $\begin{array}{c}0.004 * * \\
(2.521)\end{array}$ \\
\hline YEAR & YES & YES & YES & YES \\
\hline INDUSTRY & YES & YES & YES & YES \\
\hline $\mathrm{N}$ & 192 & 192 & 192 & 192 \\
\hline $\mathrm{r} 2 \mathrm{a}$ & 0.1311 & 0.1521 & 0.1856 & 0.1857 \\
\hline
\end{tabular}

Table IV reports the test results of model (4). We add the cross-term PRO $\times \mathrm{SOE}$ to model (1) to examine the moderating effect of property rights. According to the fullsample regression results, the coefficient of $\mathrm{PRO} \times \mathrm{SOE}$ is $0.102(p=0.01)$, and the coefficient sign is negative, indicating that compared with state-owned enterprises, the association between performance commitments and earnings management is more pronounced in non-stateowned firms. According to the sub-sample regression results, there is a positive correlation between performance commitments and earnings management in the non-stateowned enterprise, with a correlation coefficient of $0.256(p=0.01)$, which also validates H3.

Table IV Empirical results of H3

\begin{tabular}{cccc}
\hline & Full-sample & State-owned & Non-state-owned \\
& REM & REM & $0.256^{* * *}$ \\
PRO & $0.313^{* * *}$ & 0.204 & $(4.460)$ \\
& $(3.284)$ & $(1.146)$ & \\
SOE & $-0.059^{* * *}$ & & \\
& $(4.561)$ & & \\
PRO $\times$ SOE & $-0.102^{* * *}$ & & $0.019^{* * *}$ \\
& $(3.987)$ & $0.020^{* * *}$ & $(5.632)$ \\
SIZE & $0.012^{* * *}$ & $(7.125)$ & $0.139^{* * *}$ \\
& $(4.814)$ & $0.132^{* * *}$ & $(5.239)$ \\
LEV & $0.139^{* * *}$ & $(4.569)$ & $0.512^{* * *}$ \\
& $(7.103)$ & $0.513^{* * *}$ & $(4.125)$ \\
ROE & $0.602^{* * *}$ & $(3.748)$ & $0.065^{*}$ \\
& $(4.3917)$ & $0.065^{*}$ & $(1.000)$ \\
INV & $0.067^{*}$ & $(1.002)$ & 0.018 \\
& $(1.042)$ & 0.018 & $(1.013)$ \\
CEO & 0.017 & $(1.003)$ & $0.175^{* * *}$ \\
& $(0.971)$ & $-0.180^{* * *}$ & $(6.555)$ \\
IDP & $-0.169^{* * *}$ & $(4.986)$ & $0.032^{* * *}$ \\
& $(3.515)$ & $0.023^{* * *}$ & $(5.616)$ \\
GROWTH & $0.021^{* *}$ & $(4.562)$ & YES \\
& $(2.104)$ & YES & YES \\
YNDER & YES & YES & \\
YEST & YES & & \\
& & & \\
& & &
\end{tabular}




\begin{tabular}{cccc}
$\mathrm{N}$ & 192 & 86 & 106 \\
$\mathrm{r} 2 \_\mathrm{a}$ & 0.1337 & 0.1459 & 0.1543 \\
\hline
\end{tabular}

\subsection{Robustness checks}

A firm's decision to sign performance commitment may be non-random and this may cause a self-selection bias. We adopt the Heckman two-step model to test the possible selfselection issue. In the first step, we build a Probit model that affects whether companies sign performance compensation commitments, use PRO as the explained variable, perform Probit regression, and calculate the inverse Mills index (lambda). Then, the inverse Mills index (lambda) is substituted into the second stage model regression. According to the Heckman two-stage test results reported in Table $\mathrm{V}$, we find that after controlling the sample self-selection problem, the research conclusions of this paper are still valid.

Table V Heckman-The second stage regression results

\begin{tabular}{|c|c|c|}
\hline \multicolumn{3}{|c|}{ REM } \\
\hline & Coefficients & $\mathrm{T}$ \\
\hline PRO & $0.210^{* * *}$ & 5.387 \\
\hline lambda & -0.132 & -1.100 \\
\hline CPRO & $0.280 * * *$ & 5.236 \\
\hline RPRO & $0.150 * * *$ & 6.096 \\
\hline $\mathrm{PRO} \times \mathrm{SOE}$ & $0.105^{* * *}$ & 5.723 \\
\hline SIZE & $0.010 * * *$ & 4.896 \\
\hline LEV & $0.132 * * *$ & 3.472 \\
\hline ROE & $0.590 * * *$ & 3.590 \\
\hline INV & $0.050^{*}$ & 7.284 \\
\hline CEO & 0.015 & 4.905 \\
\hline IDP & $-0.158 * * *$ & 4.714 \\
\hline GROWTH & $0.019 * *$ & 4.751 \\
\hline YEAR & YES & YES \\
\hline INDUSTRY & YES & YES \\
\hline $\mathrm{N}$ & & \\
\hline r2_a & & \\
\hline
\end{tabular}

\section{Conclusions}

Performance commitment is one of the important mechanisms in M\&A activities, which has received extensive attention from the capital market, regulatory agencies and academia. However, there is little literature to study the potential risks in the current backdoor performance commitment mechanism, especially the impact of backdoor performance commitment signing on the earnings management activities of listed companies. This paper analyzes the impact of backdoor performance commitments on the earnings management of listed companies, and draws the following conclusions: a) Backdoor listed companies with signed performance commitment contracts have higher earnings management level than those without; b) the promised performance growth rate is positively correlated with the earnings management level; share compensation has a stronger impact on earnings management of backdoor listed company than cash compensation; c) compared with stateowned enterprises, the association between performance compensation commitments and earnings management is more pronounced in non-state-owned firms.

The research conclusions of this article provide the following enlightenment for how to improve the performance commitment mechanism in our country: First, the backdoor company, as a performance promiser, should strengthen its own contract awareness and avoid blind promises in pursuit of high premiums; second, investors should realize that the high promised profit is not a sufficient guarantee for the efficiency and effectiveness, and they should carefully judge the restructuring activities to avoid damage to their interests; third, regulatory agencies should strengthen the supervision and review of the signing and fulfilment of performance commitments by listed companies, regulate corporate mergers and acquisitions and reorganization, and protect the legitimate rights and interests of investors.

\section{REFERENCES}

1. Lu, C.J., Han, H.B. (2014) Performance Compensation Commitment, Synergy and M\&A Income Distribution. Audit and Economic Research. 29(6): 3-13.

2. Pan, A.L., Qiu, J.L., Yang, Y. (2017) Research on the Incentive Effects of Performance Compensation Commitments on Target Companies-Empirical Tests from Listed Companies. Accounting Research. 3: 46-52, 95 .

3. Du, Y.Q., Fei, Y.W. (2017) Can the Performance Commitment System Solve the Problem of Large Shareholders' Benefit Transmission? Investment Research. 36(07):79-90.

4. Dou, W., Fang, J. (2018) Listed companies M\&A payment methods and performance commitments. Business Research. 9: 84-90.

5. Wang, J.D., Fan, Q.Q. (2017) Research on Performance Commitment and Policy Impact in the M\&A and Reorganization of Listed Companies. Accounting Research. 10:71-77, 97.

6. Zhao, L.X., Yao, Y.W. (2014) Operational analysis and improvement suggestions on the restructuring profit forecast compensation system. Securities Market Herald. 04: 4-8+15.

7. Jian, G.Q., Li, B.X., Li, H. (2019) Performance compensation commitment, R\&D investment and fixed-increased M\&A value creation. Modern Finance. 39(04): 51-61.

8. Hou, Q., Jin, Q., Yang, R., et al. (2015) Performance Commitments of Controlling Shareholders and Earnings Management. Contemporary Accounting Research. 2(3): 1099-1127. 
9. Cadman, D.R. (2012) Controlling Shareholder Equity Pledge and Real Earnings Management of Listed Companies. Accounting Research. 8: 21-27.
10. Chen, B.K., Lin, Y.F. (2012) Financial Repression, Industrial Structure and Income Distribution. World Economy. 35(01): 3-23. 